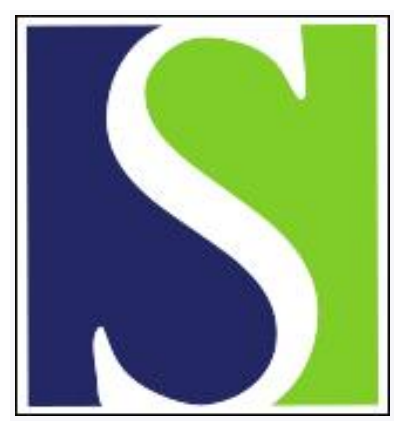

Scand J Work Environ Health 1996;22(1):34-38

https://doi.org/10.5271/sjweh.106

Issue date: Feb 1996

Pulmonary asbestos bodies and asbestos fibers as indicators of exposure

by Karjalainen A, Nurminen M, Vanhala E, Vainio $H$, Anttila S

Key terms: anthophyllite; crocidolite; electron microscopy; optical microscopy

This article in PubMed: www.ncbi.nlm.nih.gov/pubmed/8685671

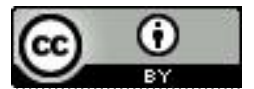




\title{
Pulmonary asbestos bodies and asbestos fibers as indicators of exposure
}

\author{
by Antti Karjalainen, MD, ${ }^{1}$ Markku Nurminen, PhD, ${ }^{1}$ Esa Vanhala, MSc, ${ }^{1}$ Harri Vainio, MD, \\ Sisko Anttila, $M D^{1}$
}

\begin{abstract}
Karjalainen A, Nurminen M, Vanhala E, Vainio H, Anttila S. Pulmonary asbestos bodies and asbestos fibers as indicators of exposure. Scand J Work Environ Health 1996:22:34-8.
\end{abstract}

\begin{abstract}
Objectives The aim of the study was to analyze the correlation between pulmonary concentrations of asbestos bodies and asbestos fibers and to characterize asbestos body counts from lung tissue of Finnish patients occupationally exposed and unexposed to asbestos.

Methods Ninty-nine surgically treated lung cancer patients were investigated. The number of asbestos bodies in iron-stained $5-\mu \mathrm{m}$ histological lung tissue sections was determined by optical microscopy, and the pulmonary concentration of asbestos fibers was assessed by scanning electron microscopy. The correlation between asbestos body and asbestos fiber counts was calculated with linear regression. The asbestos body and asbestos fiber concentrations were also compared with exposure history according to a personal interview of the patients. Results The average number of asbestos bodies ranged from $<0.1$ to 750 asbestos bodies per tissue section. All the cases with definite exposure showed an average of at least one asbestos body per tissue section. An average of at least one asbestos body per section was, however, detected in 34\% of the patients with unlikely exposure. The regression equation $\log (\mathrm{AF})=-0.429+0.600 \cdot \log (\mathrm{AB})$ was found to predict the concentration of asbestos fibers (AF, $10^{6}$ fibers $\cdot \mathrm{g}^{-1}$ ) corresponding to a given number of asbestos bodies $(\mathrm{AB}$ ) in a section of lung tissue.

Conclusions The background level of asbestos bodies in the lungs of patients with no specific asbestos exposure seems to be higher in Finland than in other countries. In medicolegal cases, the methodological variation involved in asbestos fiber and asbestos body counting must be recognized and all available exposure data should be used to produce the best possible estimate of the exposure.
\end{abstract}

Key terms anthophyllite, crocidolite, electron microscopy, optical microscopy.

Occupational exposure to asbestos was common earlier in most industrialized countries. In Finland the use of asbestos peaked in the early 1970s (1). Asbestos-related diseases have a long latency period, and despite the rapid reduction of exposure in the 1980 s the incidence of asbestos-related diseases will continue to increase during the next 10 to 20 years. Lung cancer and mesothelioma cases among asbestos-exposed workers thus constitute a growing medicolegal problem. Accurate exposure assessment is crucial in these cases. Risk estimates of lung cancer and mesothelioma associated with increased pulmonary concentrations of asbestos fibers, as well as reference fiber concentrations observed in the general population, based on results obtained with electron microscopy, have recently been published in Finland $(2,3,4)$.

In clinical routine, the intensity of asbestos exposure is often characterized by optical microscopic counts of asbestos bodies in lung tissue sections from samples taken during surgery or necropsy. Asbestos bodies are asbestos fibers that have been coated with ferroprotein by macrophages in the lung tissue (5). Their occurrence is closely associated with the concentration of amphibole asbestos fibers (6). It has been proposed that the minimum criteria for the histologic diagnosis of asbestosis include the observation of peribronchiolar fibrosis and the identification of more than one asbestos body per lung tissue section (7) and that such asbestos body concentrations indicate nontrivial exposure (8). In Finland, the use of amphibole asbestos has been common due to domestic production of anthophyllite asbestos. Approximately $40 \%$ of all asbestos used in Finland consists of amphiboles (1). It is therefore probable that the international reference values for asbestos body counts for populations exposed mainly to chrysotile are not valid for the Finnish population.

1 Finnish Institute of Occupational Health, Helsinki, Finland.

Reprint requests to: Dr Antti Karjalainen, Finnish Institute of Occupational Health, Topeliuksenkatu 41 a A, FIN-00250 Helsinki, Finland. 
The objective of this study was to analyze the correlation between asbestos body counts and concentrations of asbestos fibers, as well as to characterize the asbestos body counts observed in the lungs of Finnish patients occupationally exposed to asbestos and also those unexposed to asbestos.

\section{Subjects and methods}

\section{Patients}

The study population consisted of 99 lung cancer patients who underwent surgical lobectomy or pulmectomy in the Department of Thoracic and Cardiovascular Surgery at the Helsinki University Central Hospital between August 1988 and December 1993. The subjects were selected from 150 consecutively treated patients. In comparison with the original series the present series was reinforced with exposed patients. The mean age of the 85 men was 62.4 (range $35-79$ ) years, and the mean age of the 14 women was 62.7 (range 43-75) years. There were 50 squamous-cell carcinomas, 35 adenocarcinomas, 6 large-cell carcinomas, 7 small-cell carcinomas, and 1 adenosquamous carcinoma. According to personal interview data, five of the patients had never smoked (three men and two women).

\section{Occupational history}

The lung cancer patients were interviewed personally about their complete occupational history, including past occupational, domestic, and environmental exposure to asbestos. The probability of past occupational exposure to asbestos was evaluated by two occupational hygienists by consensus. The exposure categorization was made without any knowledge of asbestos counts from tissue samples. An exposure time of one month was regarded as the minimum. The exposure was classified into one of the following four categories according to previously described guidelines (4): definite, probable, possible, or unlikely exposure.

\section{Asbestos body counting on tissue slides}

The tissue material consisted of 53 lobectomy, 32 pulmectomy, and 14 bilobectomy samples. The lung specimens were filled with $4 \%$ formaldehyde through the bronchi and immersed in formaldehyde overnight. For the counting of asbestos bodies several samples of uninvolved lung tissue were taken and embedded in paraffin. The number of asbestos bodies per slide was calculated in 5 - $\mu \mathrm{m}$ thick iron-stained sections of the size of a biopsy cassette at $100-200 \times$ magnification. Two to nine slides per case were studied for asbestos bodies. At least three lung tissue samples per lobe, including one from the central region and one with pleura, were investigated. Previously described criteria were applied to distinguish between asbestos and nonasbestos bodies (5).

\section{Electron microscopy}

The tissue pieces for electron microscopic fiber analysis were taken from the peripheral part of the lung, not including pleural or tumor tissue. In cases of bilobectomy or pulmectomy, the sample was taken from the lobe which appeared to be closest to normal.

A tissue piece of about $100 \mathrm{mg}$ wet weight was taken for the fiber analysis. Organic tissue was removed by low temperature ashing. Fibers were detected with a JEOL 100 CX-ASID4D electron microscope in the scanning (SEM) mode at a magnification of 5000-fold (3). A length- to -width ratio greater than 3 and roughly parallel sides were used as fiber criteria. Fibers longer than $1 \mu \mathrm{m}$ could be detected. A minimum of 200 viewing fields was evaluated to find at least 4 to 30 fibers per sample, depending on the density. An analytical sensitivity (one fiber per sample) of about $0.1 \cdot 10^{6}$ fibers per gram ( $\mathrm{f} \cdot \mathrm{g}^{-1}$ ) of dry tissue could be reached.

An energy dispersive X-ray microanalyzer (Tracor TN 5500, Tracor Europa BV, Bildhoven, The Netherlands) was used to determine the fiber type by comparing peak ratios to standard spectra. Amosite and crocidolite have almost similar X-ray spectra and are distinguished poorly. They have not therefore been presented separately. In a previous Finnish study, crocidolite fibers accounted for the great majority of the amosite or crocidolite fibers identified with transmission electron microscopy (9). Chrysotile fibers are poorly detected with SEM, and consequently the results represent the concentration of amphibole fibers.

\section{Statistical analyses}

The differences in the distribution of asbestos body and asbestos fiber concentrations between the exposure groups were analyzed with Duncan's multiple range test adjusted for age. The distributions of the asbestos body and asbestos fiber concentrations were approximately $\log$ normal, and $\log$ transformed concentrations were therefore used in the statistical analyses. The regression equation predicting the underlying pulmonary asbestos fiber concentration from the measured number of asbestos bodies per tissue section was calculated with linear regression of the logged concentrations. In 10 of the samples no asbestos fibers, in three of the samples no asbestos bodies, and in four of the samples neither asbestos fibers nor asbestos bodies were encountered. For the data analysis, concentrations of $0.05 \cdot 10^{6} \mathrm{f} \cdot \mathrm{g}^{-1}$ and 0.05 asbestos bodies per section, respectively, were used for the data points; this procedure had only a minor effect in the regression analysis. 


\section{Results}

\section{Asbestos bodies in tissue sections}

The average number of asbestos bodies in histological lung tissue sections ranged from $<0.1$ to 750 asbestos bodies per tissue section (table 1). The highest numbers were observed in the group with definite occupational exposure to asbestos, and all of the cases in this group showed an average of at least one asbestos body per tissue section. Asbestos bodies were, however, frequently detected in tissue sections of patients with unlikely occupational exposure to asbestos, and $34 \%$ of the patients in this group showed an average of more than one, and $24 \%$ more than two, asbestos bodies per tissue section (maximum 7.9). Despite the substantial overlapping in the asbestos body concentration readings between the exposure groups, there was a significant difference (Duncan's multiple range test at $\mathrm{P}=0.05$ ) in the distribution of the asbestos body concentrations between all of the exposure groups. Age was found to correlate with the asbestos body concentrations (analysis of covariance, $\mathrm{P}=0.02$ ) and was therefore adjusted for in the comparisons between the exposure groups.

Table 1. Number of asbestos bodies in standard histological lung tissue sections by probability of occupational exposure to asbestos, as evaluated from the work history of 99 Finnish lung cancer patients.

\begin{tabular}{lcccccr}
\hline \multirow{2}{*}{$\begin{array}{l}\text { Exposure } \\
\text { group }\end{array}$} & $\begin{array}{c}\text { Number } \\
\text { of } \\
\text { patients }\end{array}$ & \multicolumn{5}{c}{ Asbestos bodies per tissue section } \\
\cline { 3 - 7 } & & $\begin{array}{c}\text { Range } \\
(\mathrm{N})\end{array}$ & $\begin{array}{c}\text { Median } \\
(\mathrm{N})\end{array}$ & $\begin{array}{c}\geq 1 \\
(\%)\end{array}$ & $\begin{array}{c}\geq 10 \\
(\%)\end{array}$ & $\begin{array}{r}\geq 100 \\
(\%)\end{array}$ \\
\hline Definite & 15 & $1.2-750$ & 20 & 100 & 80 & 40 \\
Probable & 26 & $0.3-100$ & 3.0 & 77 & 23 & 8 \\
Possible & 29 & $<0.1-150$ & 1.0 & 59 & 10 & 3 \\
Unlikely & 29 & $<0.1-7.9$ & 0.5 & 34 & 0 & 0 \\
\hline
\end{tabular}

\section{Asbestos fibers in lung tissue}

The concentration of asbestos fibers ranged from $<0.1$ to $150 \cdot 10^{6} \mathrm{f} \cdot \mathrm{g}^{-1}$ (table 2 ). The highest concentrations in the group of unlikely occupational exposure were slightly above $1 \cdot 10^{6} \mathrm{f} \cdot \mathrm{g}^{-1}$, these were mainly anthophyllite fibers (table 2). The highest concentration of crocidolite or amosite fibers in this exposure group was $0.3 \cdot 10^{6} \mathrm{f} \cdot \mathrm{g}^{-1}$. The distribution of asbestos fiber concentrations differed significantly (Duncan's multiple range test at $\mathrm{P}=0.05$ ) between the exposure groups, except between the groups of unlikely and possible exposure. Age was found to correlate with the concentration of asbestos fibers (analysis of covariance, $\mathrm{P}=0.06$ ) and was therefore adjusted for in the comparisons between the exposure groups. The correlation between age and concentration of asbestos fibers was due to the correlation between age and the concentration of anthophyllite fibers $(\mathrm{P}=0.005)$. There was no significant correlation between age and the concentration of crocidolite or amosite fibers $(\mathrm{P}=0.58)$

\section{Correlation between the concentration of asbestos bodies and the concentration of asbestos fibers}

The correlation ( $\mathrm{r}$ ) between $\log$ concentrations of asbestos bodies and asbestos fibers was highly significant $(\mathrm{r}=0.73, \mathrm{P}<0.001)$. Figure 1 shows a scatter diagram of the 99 pairs of asbestos body and asbestos fiber concentrations on a log scale. The simple regression equation was $\log (\mathrm{AF})=-0.429+0.600 \cdot \log (\mathrm{AB})$, where $\mathrm{AF}=$ pulmonary concentration of asbestos fibers $\left(10^{6} \mathrm{f} \cdot \mathrm{g}^{-1}\right)$ and $\mathrm{AB}=$ average number of asbestos bodies per standard histological lung tissue section.

Most of the exposed patients had been exposed both to anthophyllite and crocidolite or amosite, and there was a close correlation between the pulmonary concentrations of these fibers $(r=0.49, \mathrm{P}<0.001)$. When both

Table 2. Pulmonary concentration (scanning electron microscopy) of total asbestos fibers, anthophyllite and crocidolite or amosite fibers by probability of occupational exposure to asbestos, as evaluated from the work history of 99 Finnish lung cancer patients.

\begin{tabular}{|c|c|c|c|c|c|c|}
\hline \multirow[t]{2}{*}{ Fiber type } & \multirow{2}{*}{$\begin{array}{l}\text { Number } \\
\text { of } \\
\text { patients }\end{array}$} & \multicolumn{5}{|c|}{ Pulmonary fiber concentration $\left(10^{6} f \cdot \mathrm{g}^{-1}\right)$} \\
\hline & & Range & Median & $\geq 0.1(\%)$ & $\geq 1.0(\%)$ & $\geq 10.0(\%)$ \\
\hline \multicolumn{7}{|l|}{ Total asbestos } \\
\hline $\begin{array}{l}\text { Definitely exposed } \\
\text { Probably exposed } \\
\text { Possibly exposed } \\
\text { Unlikely exposed }\end{array}$ & $\begin{array}{l}15 \\
26 \\
29 \\
29\end{array}$ & $\begin{array}{l}0.5-150 \\
<0.1-13 \\
<0.1-4.5 \\
<0.1-1.4\end{array}$ & $\begin{array}{l}5.9 \\
0.84 \\
0.46 \\
0.26\end{array}$ & $\begin{array}{r}100 \\
96 \\
72 \\
69\end{array}$ & $\begin{array}{r}87 \\
46 \\
24 \\
7\end{array}$ & $\begin{array}{r}40 \\
8 \\
0 \\
0\end{array}$ \\
\hline \multicolumn{7}{|l|}{ Anthophyllite } \\
\hline $\begin{array}{l}\text { Definitely exposed } \\
\text { Probably exposed } \\
\text { Possibly exposed } \\
\text { Unlikely exposed }\end{array}$ & $\begin{array}{l}15 \\
26 \\
29 \\
29\end{array}$ & $\begin{array}{l}<0.1-71 \\
<0.1-8.9 \\
<0.1-3.6 \\
<0.1-1.1\end{array}$ & $\begin{array}{l}1.2 \\
0.38 \\
0.27 \\
0.12\end{array}$ & $\begin{array}{l}87 \\
81 \\
72 \\
62\end{array}$ & $\begin{array}{r}60 \\
27 \\
21 \\
7\end{array}$ & $\begin{array}{r}20 \\
0 \\
0 \\
0\end{array}$ \\
\hline \multicolumn{7}{|l|}{ Crocidolite or amosite } \\
\hline $\begin{array}{l}\text { Definitely exposed } \\
\text { Probably exposed } \\
\text { Possibly exposed } \\
\text { Unlikely exposed }\end{array}$ & $\begin{array}{l}15 \\
26 \\
29 \\
29\end{array}$ & $\begin{array}{l}<0.1-74 \\
<0.1-6.8 \\
<0.1-1.0 \\
<0.1-0.32\end{array}$ & $\begin{array}{l}4.2 \\
0.37 \\
0.10 \\
<0.10\end{array}$ & $\begin{array}{l}80 \\
69 \\
48 \\
14\end{array}$ & $\begin{array}{r}53 \\
23 \\
0 \\
0\end{array}$ & $\begin{array}{r}27 \\
0 \\
0 \\
0\end{array}$ \\
\hline
\end{tabular}


the concentration of anthophyllite fibers and the concentration of crocidolite or amosite fibers were included in the statistical model (multiple linear regression), both were found to correlate closely with the asbestos body concentrations ( $\mathrm{P}<0.001$ for both fiber types).

\section{Discussion}

Asbestos has been widely used in most industrialized countries. The general knowledge on asbestos exposure in various jobs and industries can be used to rule out typical occupational exposures to asbestos fairly accurately. Occult low exposures to asbestos have, however, taken place on various nonoccupational or paraoccupational occasions (eg, renovation of houses or public buildings). These were often not comprehended by the exposed persons. Such exposures are therefore difficult to identify even with a thorough personal interview. Such a background level of asbestos exposure exists in all societies. Chrysotile asbestos has constituted more than $90 \%$ of all asbestos used in most countries in contrast to only about $60 \%$ in Finland (1). Many of the background exposures that, in other countries, consist of chrysotile fibers consist of anthophyllite fibers in Finland. It has been proposed that the minimum criteria for the histological diagnosis of asbestosis include the observation of peribronchiolar fibrosis and the identification of more than one asbestos body per lung tissue section (7) and that such asbestos body concentrations indicate nontrivial exposure (8). In our series, somewhat higher concentrations of asbestos bodies were occasionally observed among the patients with no apparent occupational or nonoccupational exposure to asbestos. As asbestos bodies are formed more readily from amphibole fibers than from chrysotile fibers, it is logical that the background level of asbestos bodies in lung tissue is higher in Finland than in other countries. It is noteworthy that in our series the highest concentrations of asbestos fibers in the group of unlikely occupational exposure consisted of anthophyllite fibers and not of crocidolite or amosite fibers and that the differences between the exposure groups seemed to be larger for crocidolite or amosite fibers than for anthophyllite fibers (table 2). This finding is in accordance with the results of a series of 300 lung tissue samples of Finnish men representing the general urban population (3) and may explain the lack of an association between age and the concentration of crocidolite or amosite fibers.

According to the regression equation in figure 1, about five asbestos bodies per lung tissue section would correspond to a pulmonary asbestos fiber concentration of $1 \cdot 10^{6} \mathrm{f} \cdot \mathrm{g}^{-1}(95 \%$ confidence limits for the predicted mean $0.7-1.3 \cdot 10^{6} \mathrm{f} \cdot \mathrm{g}^{-1}$ ). When the regression equation is used to predict the underlying pulmonary concen-

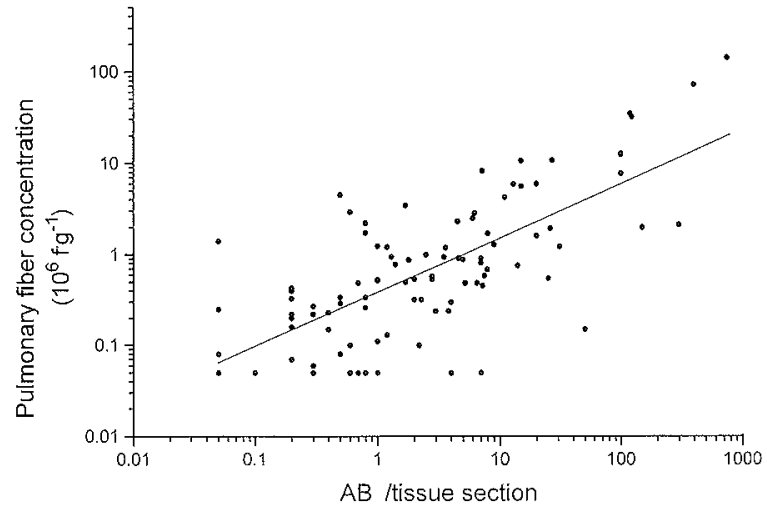

Figure 1. Scattergram of asbestos body $(A B)$ counts in histologicallung tissue sections and pulmonary asbestos fiber concentrations (scanning electron microscopy) from 99 Finnish lung cancer patients.

tration of asbestos fibers, it must be noted that in individual cases the ratio between fiber concentration and number of asbestos bodies ranges widely. For example, in cases with an average count of four to five asbestos bodies per section, the asbestos fiber concentration ranged from $<0.1$ to $2.3 \cdot 10^{6} \mathrm{f} \cdot \mathrm{g}^{-1}$. (See figure 1.) The following factors may contribute to the observed variation in individual cases: topographic variations in concentrations of asbestos fibers and asbestos bodies; a poorer precision in asbestos body counting for highly exposed persons; the use of nonstandardized section area in asbestos body counting; differences in fiber dimensions, fiber types, and possibly also in host factors affecting the coating of fibers. It is also noteworthy that, a1though the great majority of the so-called asbestos bodies or ferruginous bodies are formed on asbestos fibers, nonasbestos bodies have constituted a high proportion of all coated fibers in foundry workers (10). Two foundry workers were included in our series, and they both showed an unusually high "asbestos" body count in respect to the pulmonary asbestos fiber concentration (50 and 25 asbestos bodies per section versus 0.15 and $0.55 \cdot 10^{6} \mathrm{f} \cdot \mathrm{g}^{-1}$, respectively).

For our patients the fiber concentration was determined from a single, relatively small sample. When pulmonary fiber analyses are used at the individual level, it may be preferable to use several samples from different parts of the lung to improve the analytical reliability. A wide variation in the fiber counts has been observed in interlaboratory comparisons, and laboratory-bound reference values should be used (11).

It has been concluded that the number of asbestos bodies in iron-stained lung tissue sections is a relatively accurate predictor of the pulmonary concentration of asbestos bodies determined with standardized tissue digestion methods $(8,12)$. It must be emphasized that the asbestos body counts made from tissue sections in our study were based on careful and systematic screening of 
the entire $5 \mu \mathrm{m}$ section at a moderately high magnification $(100-200 \times)$, which is a relatively time-consuming procedure. These asbestos body counts cannot be compared with those made from hematoxylin-eosin-stained sections or casual inspection of iron-stained sections. It must also be emphasized that further methodological inaccuracy arises from the calculation of the asbestos body concentration per standard tissue section and not per exact tissue section area. Because of these methodological problems and the variation in the ratio asbestos bodies : asbestos fibers, it is preferable to combine all data available (work history, radiological and histological findings, and lung fiber or asbestos body concentrations) to arrive at the best possible estimate of the intensity of exposure in medicolegal cases. If considerable weight must be given to lung tissue analysis (eg, cases with inconclusive work history), it may be preferable to ascertain the asbestos body counts in tissue sections with more standardized methods, unless the observed asbestos body counts are very high.

\section{References}

1. Ministry of Labour. Asbestikomitean mietintö [Report of the Asbestos Committee]. Helsinki: Ministry of Labour, 1989. Report series of governmental committees, no 66. English summary.

2. Tuomi T, Huuskonen MS, Virtamo M, Tossavainen A, Tammilehto $\mathrm{L}$, Mattson $\mathrm{K}$, et al. Relative risk of mesothelioma associated with different levels of exposure to asbestos. Scand J Work Environ Health 1991;17:404-8.

3. Karjalainen A, Vanhala E, Karhunen P, Lalu K, Penttilä A, Tossavainen A. Asbestos exposure and pulmonary fiber con- centration of 300 Finnish urban men. Scand J Work Environ Health 1994;20:34-41.

4. Karjalainen A, Anttila S, Vanhala E, Vainio H. Asbestos exposure and the risk of lung cancer in a general urban population. Scand J Work Environ Health 1994;20:243-50.

5. Churg AM, Warnock ML. Asbestos and other ferruginous bodies; their formation and clinical significance. Am J Pathol 1981;102:447-56.

6. Albin M, Johansson L, Pooley FD, Jakobsson K, Attewell R, Mitha R. Mineral fibres, fibrosis, and asbestos bodies in lung tissue from deceased asbestos cement workers. Br J Ind Med 1990;47:767-74

7. Craighead JE, Abraham JL, Churg A, Green FHY, Kleineman J, Pratt PC, et al. The pathology of asbestos-associated diseases of the lungs and pleural cavities: diagnostic criteria and proposed grading schema. Arch Pathol Lab Med 1982;106: 544-96.

8. Roggli VL, Pratt PC. Numbers of asbestos bodies on ironstained tissue sections in relation to asbestos body counts in lung tissue digests. Hum Pathol 1983;14:355—61.

9. Anttila S, Karjalainen A, Taikina-Aho O, Kyyrönen P, Vainio $H$. Lung cancer in the lower lobe is associated with pulmonary asbestos fiber count and fiber size. Environ Health Perspect 1993;101:166-70.

10. Dodson RF, O'Sullivan M, Corn CJ, Garcia JGN, Stocks JM, Griffith DE. Analysis of ferruginous bodies in bronchoalveolar lavage from foundry workers. Br J Ind Med 1993;50: 1032-8.

11. Gylseth B, Churg A, Davis JGM, Johnson N, Morgan A, Mowe G, et al. Analysis of asbestos fibers and asbestos bodies in tissue samples from human lung. Scand $J$ Work Environ Health 1985;11:107-10.

12. Vollmer RT, Roggli VL. Asbestos body concentrations in human lung: predictions from asbestos body counts in tissue sections with a mathematical model. Hum Pathol 1985;16: 713-8.

Received for publication: 30 January 1995 